\title{
Testing the Feasibility of Project Book Design Geotechnical Engineering That Assisted with the PLAXIS 2D Application
}

\author{
S Suhairiani ${ }^{1, *}$ Nahesson Panjaitan ${ }^{1,}$ Enny Keristiana Sinaga ${ }^{2}$ \\ ${ }^{1}$ Department of Civil Engineering, Faculty of Engineering, Universitas Negeri Medan, Indonesia \\ ${ }^{2}$ Department of Building Engineering Education, Faculty of Engineering, Universitas Negeri Medan, Indonesia \\ *Corresponding author.Email: suhairiani@unimed.ac.id
}

\begin{abstract}
This research aims to assess the feasibility of project book Geotechnical Engineering assisted Plaxis 2D application which has a function as an increase in hard skills for the students in applying the concept of learning Geotechnical Engineering with Computer Application. The method of this research uses Research and Development with the development model is Borg and Gall. The subjects of this research are Civil Engineering students who take the subject of Geotechnical Engineering with Computer Application and the object of this research is a project book that will be validated by 2 validators (media and materials) and 1 practicality lecturer. From the three testing feasibility that have been done, and that have been obtained the results show that the teaching materials are feasible to be developed and practical to be used as an effort to bring up hard skills in the field of geotechnical.
\end{abstract}

Keywords: Feasibility, Geotechnical Engineering, Book Design.

\section{INTRODUCTION}

Geotechnical is a tool in the plan or design of a building [1]. Data planning of Geotechnical must be used correctly and carefully with the assumptions and limitations that have been set, and used to achieve the results that we want. Work of Geotechnical is to give guidelines regarding geotechnical potential that will occur, the scope in ths work of Geotechnical such as work of excavation and soil embankment, foundation planning of a building, underground building planning such as tunnel, soil excavation planning, dam planning, building planning of landslide retaining and work of building foundation [2].

Geotechnical Engineering with applications of computer is an elective subject in the concentration of Geotechnical expertise in the undergraduate of study program of Civil Engineering, in this subject, the students are expected to have one of abilities in the science of geotechnical, so that with the skills that are possessed by a student, eventually, they will be able to solve problems from geotechnical cases that exist, in the end ths students not only understand and master about the theory, but also can apply the theory in the form of cases with helping applications of computer. The application that is used is the Plaxis software application. Plaxis program is a finite element method modeling and postprocessing program that able to analyze geotechnical problems in the civil planning that approximates the actual soil behavior [3].

Implementation of the subject of Geotechnical Engineering with Computer has four (4) targets that are achieved, these are:(1) giving knowledge and ability (skill) about Geotechnical engineering to the students; (2) giving provision of practical skills in the form of the use of application that is used in Geotechnical; (3) giving an overview and experience to solve the problems or cases tha are related to the geotechnical engineering and (4) training students to be able to communicate the results of their studies by using the applications. To support the four (4) targets above, learning project that is based on ICT is needed, where the cases will be provided that must be resolved by using a Geotechnical application by using Plaxis software 8.2 as one of the facilities of ICT, to assist in analyzing the problems that are contained in the world of Geotechnical construction. In other words, the use of computer software for learning activities is not very limited, in 
other words, the potential of technology in the computer as a medium in this learning is very substantial.

The results of the analysis of the situation above, the researcher sees the needing development of teaching materials other than the textbooks that are used in the learning. Teaching materials are basically all materials (both information, tools, and texts) that are systematically arranged that display a complete figure of competencies that will be mastered by students and used in the learning process with the aim of planning and reviewing the implementation of learning [4]. The teaching materials that will be developed are in the form of textbooks (a unit of learning that contains of information, discussion and evaluation [5] in the form of a project book (buject) to facilitate studying geotechnical problems using the Plaxis application. In that book will develop not only make material content but also in the form of a collection of cases and problem solving of geotechnical problems that often arise in the world of construction use the Plaxis application, that all aim to improve hard skills on Geotechnical. The combination of textbooks in the form of this buject will be able to help the students learn effectively. Independent and more active in honing geotechnical problem of solving skills, so that the process of learning activities becomes smoother and more effective and can be used for memory strengthening activities, concept understanding, critical thinking and ability improvement (hard skills) [6].

Based on the results of the analysis of the problems above, the first step of researcher after the draft of the project book is designed is a testing feasibility. The testing feasibility or validity comes from the word validity which means validity or the way it should apply. Validity is a measure that shows the level of validity of a test. A test is said to be valid if the test can measure what is measured [7] states that: - A test is said to have content validity if it measures certain specific objectives that are parallel to the material or content of the lesson that is given. The testing feasibility is done by the validator with presenting several experts that have experienced to assess the teaching materials that are designed. Every expert is asked to assess the teaching materials, then after that can be identified the weaknesses and strengths. The testing feasibility is done by respondents from the expert model or product design. This activity is done to review the initial product, giving suggestion for correction.

The step of testing validity [8] is done with the way: (1) asking the willingness of lecturer who has a lot of teaching experience to become validator from the printed teaching materials that have been developed; (2) Giving a score of answers with criteria based on a Likert scale. likert scale is used to measure attitudes, opinions, and a person's perceptions about social phenomena [9]; (3) Asking the validator to give advice based on the assessment that is given to the development of printed teaching materials based on the items that are contained in the testing validity. If there are still many errors in the development of printed teaching materials, it is necessary to revise so that the teaching materials that are developed are truly valid; (4) finding the total score of each validator with adding up all the scores that are obtained from each indicator; (5) finding and giving a feasibility assessment.

Testing feasibility on this textbook will be done by two validators (media expert and material expert) and one lecturer practicality to see and assess whether the project book is suitable ti be used as a medium in learning activities in the subject of geotechnical engineering with computer application to improve the student hard skills as capital of scientific basis in the world of job construction in the field of geotechnical engineering.

\section{RELEVANT WORK}

This research is inseparable from the results of the researches that have been done as comparison materials, such as the research that has been done by Dhia Octariani (2018) with the title is pengembangan bahan ajar berbasis project based learning berbantuan software Geogebra [10]. The Research that uses the model of Borg \& Gall states that a textbook this contain cases of problems then solved with the help of software can grow the ability of the students to solve existing problems, in this research is also passed the process of testing validity that has been done by the experts and obtained good results. so that the teaching materials that will be planned later are suitable to be used as a source of learning in teaching and learning activities.

\section{METHOD}

This study uses the Research and Development (R\&D) method which refers to the Borg and Gall model [11] in [12]. The research and development steps that will be carried out are as shown in Fig.1 below.

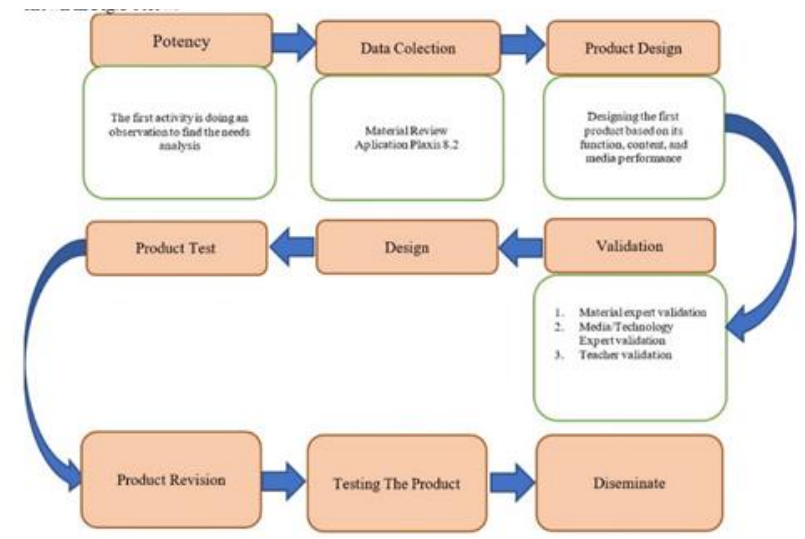

Figure 1 Research and Development step

In this article, the researcher only limits until to the stage of testing feasibility by validators of material expert, media expert, and validators of lecturer, it is 
because this article only looks at the feasibility of the product that will be developed later. The final product of this $R \& D$ is in the form of learning media, that is textbook in the form of project book (buject). The subject of this research is the students who take the subject of geotechnical engineering with computer application. The instrument that is used used is product validation by validators (materials, media and lecturer).

The product of testing feasibility is done by the section of validation to the validator, it means that most of the project book is assessed based on the results of the validation that has been done by the validators of material and media and a person of a team of teaching members in the subject of Geotechnical Engineering with computer application. With each minimum educational qualification is postgraduate and has a minimum of experience for five years with has an experience about material expert in the scope of Geotechnical, media expert with has experienced in the scope of Graphics and Design and the person of the teaching teams in the subject of Geotechnical Engineering with computer application.

\subsection{Data Type}

That is collected in this research, that is in the form of quantitative and qualitative data. Quantitative data consists of numbers and classes which are analyzed statistically, and qualitative data consists of words, descriptions, pictures, diagrams, which are analyzed by category or sorting [13]. Quantitative data is obtained from the assessment [14], scores of validators and lecturers in the questionnaire assessment The data is in the form of a scale ranging from 1 - 4 which states the suitability of the product with the statement that is contained in the questionnaire of assessment [9].

\subsection{Research Instrument}

The research instrument is a questionnaire with a check mark, which aims to get an assessment from the validators (material, media and lecturer). The results of the questionnaire in this research are based on a Likert scale [9], which is translated by interval analysis as shown in this Table 1 below.

Table 1. Category of scoring [9]

\begin{tabular}{lc}
\hline Category & Score \\
\hline SB(Sangat Baik/Very Good) & 4 \\
B(Baik/ Good) & 3 \\
K(Kurang/Less) & 2 \\
KB(Sangat Kurang/Very Less) & 1 \\
\hline
\end{tabular}

\subsection{Data Analysis Technique}

The technique of data analysis in this research is data analysis of the necessary for product development in the teaching materials with using the technique of qualitative descriptive and will be explained in narratively. This data analysis includes a preliminary study of the condition of the students problems that arise during in the subject learning, materials/concepts and the aim of learning. Assessment of teaching materials are based on the syllabus in the subject of geotechnical engineering with computer application that is assisted by the Plaxis application with experts and practitioners use quantitative analysis. Technique of Data collection in this research use non-testing techniques to determine the feasibility of teaching material products in the form of project book (Buject). The non-testing technique consists of observation, interview or discussion, document review and questionnaire. Data processing in this research is done by using qualitative and quantitative analysis with the validity and feasibility of teaching material data. After the data is analyzed, it will be used to revise the product of teaching materials, to obtain products that suitable with the specified criteria, that is valid and practical.

The steps they are used to determine the validity criteria of the project book are as follows: (1) Data is the form of a questionnaire in the form of scores that are obtained from judgment expert through an assessment sheet consists of 4 assessments, as in Table 1, (2) Data is the form of scores that are obtained from the expert through sheets validation; (3) the total score that is obtained in the next research is analyzed by using a technique of quantitative descriptive evaluation that describes and interprets each component that are compared with the reference based on the mean score of ideal criteria (Mi) and the deviation score of deal standard (Sbi) by using the pattern that is developed by [15], [16] and the determination of (Mi) and (sbi) are presented in Table 2 below:

Table 2. Conversion score on scale [14], [15]

\begin{tabular}{|c|c|}
\hline Range Of The Score & Catagory \\
\hline$X>\overline{X_{i}}+1,8 s b i$ & Very Good \\
\hline$\overline{X_{i}}+0,6 s b i<X$ & \\
\hline $\begin{array}{l}\leq \overline{X_{i}} \\
+1,8 s b i\end{array}$ & Good \\
\hline$\overline{X_{i}}-0,6 s b i<X$ & \\
\hline $\begin{array}{l}\leq \overline{X_{i}} \\
+0,6 s b i\end{array}$ & Fairly Good \\
\hline$\overline{X_{i}}-1,8 s b i<X$ & \\
\hline $\begin{array}{l}\leq \overline{X_{i}} \\
-0,6 s b i\end{array}$ & Deficient \\
\hline$X \leq \overline{X_{i}}-1,8 \mathrm{sbi}$ & Very Deficient \\
\hline
\end{tabular}

With; Xi: Actual score (empirical); Mi: The ideal mean, calculated using formula $(\mathrm{Mi}=1 / 2$ (ideal maximum score + ideal minimum score);SBi: Ideal standard deviation, determined by formula $(\mathrm{SBi}=1 / 6$ (ideal maximum score - ideal minimum score). 
In this research, the project book (buject) is said to be valid if it fulfils the qualitative criteria with a minimum of good. And the practicality of using Likert scale does not enable the statement of neutral items. So that there are only two statements for the Likert scale, these are statement of positive item and statement of negative item as stated by [17] in [15] and grouped as in this Table 3 below:

Table 3. Response attitude category [16], [15]

\begin{tabular}{ccc}
\hline $\begin{array}{l}\text { Response } \\
\text { Category }\end{array}$ & Attitude & Catagory \\
\hline $\begin{array}{c}\text { Very } \quad \text { Postive } \\
\text { Attitude }\end{array}$ & $\begin{array}{l}\text { Kuartil } 3 \leq X \\
\leq \text { skor maksimal }\end{array}$ \\
Postive Attitude & Median $\leq X<$ kuartil 3 \\
Negative Attitude & Kuartil $1 \leq X<$ median \\
Very Negative & $\begin{array}{c}\text { Skor Minimal } \leq X \\
\text { Attitude }\end{array}$ & $<$ Kuartil 1 \\
\hline
\end{tabular}

Where; (1) Minimum: The minimum ot score that is obtained by each respondent is multiplied by the number of respondents; (2) Quartile I: The sum of the minimum total scores with the median divided by two; (3) Median: The sum of the maximum total score with the minimum total score divided by two; (4) Quartile 3: The sum of the maximum scores with the median divided by two. (5)Maximum: The maximum score obtained by each respondent multiplied by the number of respondents.

Practical data from this project book consists of research data from the lecturer in the subject of geotechnical engineering with computer application. Before finding the practicality criteria, it is find the minimum value, quartile 1 , median, quartile 3 and the maximum value of the project book are determined. Similar to the assessment of validity, a teaching material is said practical if it fulfils the minimum qualitative criteria for positive classification.

\section{RESULT AND DISCUSSION}

Figures and tables should be placed either at the top or bottom of the page and close to the text referring to them if possible.

\subsection{Composing of Project Book}

Textbooks are compiled based on consideration of the initial understanding of the lecturer that takes the subject of Geotechnical Engineering [18] with the computer applications. The textbook that is compiled on the basis of the concept of hard skills consist of three main aspects, these are practice, repetition, and education [19].
The three main aspects of hard skills in the subject of Geotechnical Engineering with Computer Application is described in the form: (1) Aspects of practice, that is by doing project assignments at the end of each chapter in the textbook; (2) Aspect of repetition, that is by doing substantial tasks from problems or cases that occur in the world of construction in the field of geotechnical; (3) Aspects of educational that is with the way of the students follow the subject until finish or with follow the course, webinar about the material that has been studied during srudy in the course.

The product of teaching materials in the form of the textbooks in the form of project book (buject) is based on an ICT that consists of 6 chapters are: (1) foundation subsidence; (2) excavation construction below the surface of the water; (3) river embankment construction; (4) excavation with anchors; (5) embankment construction for roads, and (6) subsidence of tunnel construction. The form of the display of the textbook is as shown in the Fig 2 below.

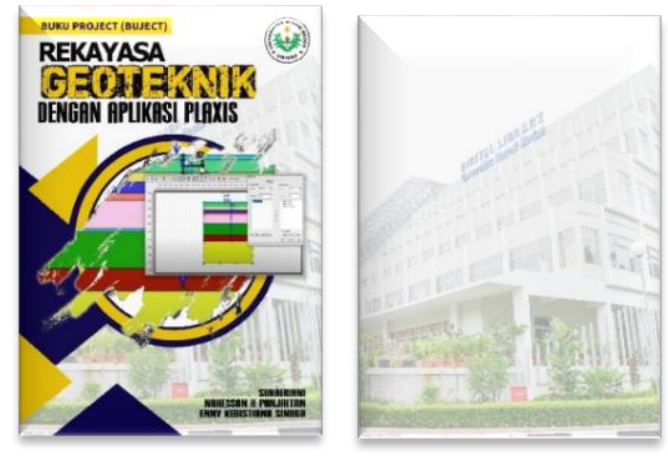

Figure 2. Project book cover front and back view

The format of the project book has a presentation sequence that consist of four parts, these are the first part is the concept of learning, in this learning concept, the students will be given an overview of what will be learned in each chapter. The learning concept consists of: achievement in the subject of this learning, subachievement in the subject of this learning, achievement indicators, and the aim of this learning (Fig. 3a). The second part is learning material, in this learning material contains a theoretical study and giving examples of application, which aim to master the basic of theoretical concepts that have been studied so that students can understand (Fig. 3b). The third part is summary that has a function to refresh the students from the material that has been studied (Fig. 3c). The fourth part is a project task that contains of questions about the material that has been studied with the aim of being able to hone or bring up scientific (hard skill) from the lessons that have been studied and to be able to measure 
therselves about the extent to which they have mastered the materials that are contained in the project book (Fig. 3d).

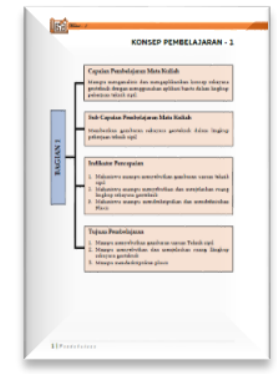

(a)

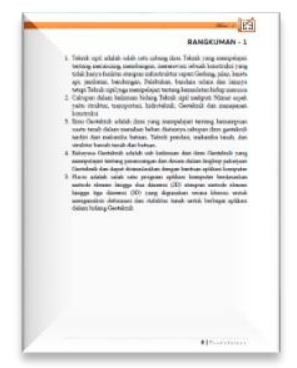

(c)

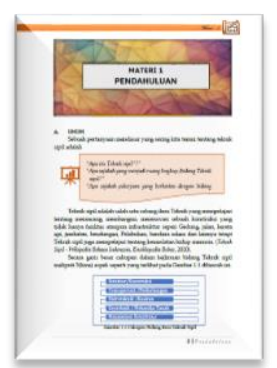

(b)

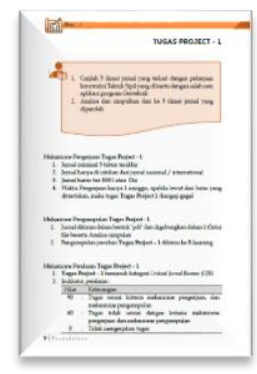

(d)
Figure 3. Example of format of presentation of project book; (a) concept of learning; (b) learning material; (c) summary; (d) project task

\subsection{Feasibility of Project Book}

This project book is validated by two experts of validator, these are material experts and media experts and one practitioner. Validators of Material expert are done by 2 (two) people who are expert in the field of Geotechnical, validators of media expert are done by two people who expert in graphic design, and validators of practitioner are taken from lecturers in the team of the subject of geotechnical engineering with computer applications.

\subsubsection{Feasibility of Material Expert}

The testing feasibility of the material is done by experts in the field of geotechnical engineering, this testing feasibility uses a questionnaire to see product validation that has been completed with a research rubric. This validation questionnaire comes from the reference of BNSP [13]. The feasibility aspect of the material expert consists of 3 aspects, these are; (1) content of feasibility aspect; (2) aspects of presentation feasibility; and (3) aspects of linguistic feasibility. The results of the validation are done by 2 (two) validators are as shown in Table 4 below.

Table 4. Material expert assesment aspect

\begin{tabular}{|c|c|c|c|c|c|}
\hline \multirow{2}{*}{ No } & \multirow{2}{*}{ Assesment Aspect } & \multicolumn{2}{|c|}{ Avarage mark } & \multicolumn{2}{|c|}{ Percentage (\%) } \\
\hline & & V1 & $\mathrm{V} 2$ & V1 & $\mathrm{V} 2$ \\
\hline 1 & Quality Of Content & 3,58 & 3,5 & 89,58 & 87,5 \\
\hline 2 & Presentation & 3,5 & 3,6 & 87,5 & 90,0 \\
\hline \multirow[t]{4}{*}{3} & Language & 3,67 & 3,56 & 91,67 & 88,89 \\
\hline & & & Total & 89,58 & 88,80 \\
\hline & & & Avarage & \multicolumn{2}{|c|}{89,19} \\
\hline & & & Catagory & \multicolumn{2}{|c|}{ Good } \\
\hline
\end{tabular}

Where; $\mathrm{V}$ is the validator.

The results of percentage that are shown in the Fig 4 above are obtained the average score for validator 1 is $89.58 \%$ and for validator II is $88.80 \%$, so that if the average values of the validators are combined and averaged, a value will be obtained $89,19 \%$, then from that value is converted into Table 2 , it will get a good category ( with $\min =31 ; \max =124 ; \mathrm{Xi}=77.50 ;$ and $\mathrm{Sbi}=15.50$ ).
From the results of the scores (Table 4), it can be concluded that the project book draft (buject) is declared proper for use in the study of geotechnical engineering with computer application, although there are several items that must be revised. Comments and suggestions from the validators of two material expert about the project book draft (buject) can be seen in Table 5 below.

Table 5. Comments and suggestions from the validators of material expert about the project book draft

\begin{tabular}{cl}
\hline Validator & \multicolumn{1}{c}{ Comment } \\
\hline Validator 1 & $\begin{array}{l}\text { More case examples are added in each discussion and Correct writing, some } \\
\text { words/sentences are still ambiguous } \\
\text { More added Practice questions and Adding a scoring mechanism and collection in } \\
\text { the tasks section }\end{array}$ \\
\hline
\end{tabular}

\subsubsection{Feasibility of Media Expert}

The media of testing feasibility is done by the experts in the field of graphic design, this testing feasibility tuses a questionnaire to see product validation that has been completed with an 
assessment rubric. This questionnaire of validation comes from the reference of BNSP [13]. The aspect of feasibility in the material expert consists of 3 aspects, these are; (1) aspect of book size; (2) aspect of book cover design; and (3)aspect of book content design. The results of the validation that is done by 2 (two) validators are as shown in this Table 5 below.

Table 5. Media expert assesment aspect

\begin{tabular}{|c|c|c|c|c|c|}
\hline \multirow{2}{*}{ No } & \multirow{2}{*}{ Assesment Aspect } & \multicolumn{2}{|c|}{ Avarage mark } & \multicolumn{2}{|c|}{ Percentage (\%) } \\
\hline & & V1 & V2 & V1 & V2 \\
\hline 1 & Size & 3,5 & 3,5 & 87,50 & 87,50 \\
\hline 2 & Cover Design & 3,43 & 3,57 & 85,71 & 89,29 \\
\hline \multirow[t]{4}{*}{3} & Content Design & 3,44 & 3,5 & 86,11 & 87,50 \\
\hline & & & Total & 86,40 & 88,10 \\
\hline & & & Avarage & \multicolumn{2}{|c|}{87,25} \\
\hline & & & Catagory & \multicolumn{2}{|c|}{ Good } \\
\hline
\end{tabular}

Where; $\mathrm{V}$ is the validator.

The results of percentage that are shown in Figure 4 above are obtained the average score for validator 1 is $86.40 \%$ and for validator II is $88.10 \%$, so that if the average values of the validators are combined and averaged, a value of will be obtained $87.25 \%$, then from that value is converted into Table 2 , then it will get a good category (with $\min =27 ; \max =108$; $\mathrm{Xi}=67.50$; and $\mathrm{Sbi}=13.50)$. From the results of the scores (Table 5), it can be concluded that the project book draft (buject) is declared proper to be use in the study of geotechnical engineering with computer application, even though there are several items that must be revised. Comments and suggestions from the two validators of media expert about the project book draft (buject) can be seen in this Table 6 below.

Tabel 6. Comments and suggestions from the validators of material expert about the project book draft

\begin{tabular}{cl}
\hline Validator & Comment \\
\hline Validator 1 & Color selection is arranged as attractive as possible, because it can affect the quality of learning \\
Validator 2 & The color gradation on the cover is smoother and Avoid using variations of letters \\
\hline
\end{tabular}

\subsubsection{Feasibility of Practicality}

The feasibility of testing practicality is done by the lecturer from the team in the subject of geotechnical engineering with computer application. This test is done to see that the teaching materials that have been made can be used and applied in the field with a good level of implementation and it is practical. This test uses a questionnaire that has been completed with an assessment rubric from the reference of BNSP [13]. The aspect of this practical consists of 4 aspects, these are; (1) aspect of material; (2) aspect of presentation (3) aspect of module; and (4) aspect of linguistics. The results of the responses are displayed in the form of a diagram as shown in this Table 7 below

Tabel 7. Aspect of response assesment by the lecture

\begin{tabular}{clcc}
\hline No & \multicolumn{1}{c}{ Assesment Aspect } & Score & Percentage (\%) \\
\hline 1 & Material & 3,85 & 77,14 \\
2 & Presentation & 3,71 & 74,28 \\
3 & Teaching Material & 3,75 & 75.00 \\
4 & Language & 3,75 & 75.00 \\
& & 3,765 & 75,35 \\
& Total/Average & Category & Very Positive Attitude \\
\hline
\end{tabular}

The results of this percentage are shown that in Fig.6 are obtained from the validation questionnaire, and from the questionnaire obtained a total value of 75,35 . Then from the total value is converted to Table 3 it will get the value of a Very Positive Attitude category (with min =
$22 ; \max =88 ; \mathrm{me}=55 ; \mathrm{Q} 1=38,5 ;$ and $\mathrm{Q} 3=71.5$ ). From the three testing feasibility that have been done by the three validators (media, material and practicality), the teaching materials are feasible to be developed, because the scores that are obtained into the feasible and practical 
category, it means that the use of teaching materials in the form of project book based on the ICT can be used by the students to learn to bring up scientific in hard skills in the field of geotechnical. [20] it is also stated that the use of learning media in the form of textbook must be arranged in a practically and attractively, [21] it is also explained that in the textbook there must also be concrete examples, because if the presentation that is given is interesting and easily understood by the students, it can make learning easier. More meaningful [22] that can think out a hard skills as the initial foundation to enter in the world of construction in the field of work of geotechnical.

\section{REFERENCES}

[1] P. S. Wulandari and D. Tjandra, "Analysis of Geotextile Reinforced Road Embankment Using PLAXIS 2D," Procedia Eng., vol. 125, pp. 358-362, Jan. 2015, DOI: 10.1016/J.PROENG.2015.11.075.

[2] A. Eslami, S. Moshfeghi, H. MolaAbasi, and M. M. Eslami, "Geotechnical engineering," Piezocone Cone Penetration Test (CPTu CPT) Appl. Found. Eng., pp. 1-23, Jan. 2020, DOI: 10.1016/B978-008-102766-0.00001-8.

[3] Bentley, "PLAXIS Geotechnical FEA Software," 2017.

https://www.bentley.com/en/products/brands/plaxis (accessed Jul. 06, 2021).

[4] P. Andi, Panduan kreatif membuat bahan ajar inovatif. Yogyakarta: Diva Press, 2012.

[5] Suhardjono, Pedoman Penyusunan Karya Ilmiah di Bidang Pendidikan Pengembangan Profesi, Kumpulan N. Jakarta: PAU P3AI Dirjen Dikti, 2001.

[6] A. S. . W. Ahmadi, Psikology Belajar. Jakarta: PT. Rineka Cipta, 2008.

[7] S. Arikunto, Dasar - Dasar Evaluasi Pendidikan (Edisi Revisi). Jakarta: Bumi Aksara, 2012.

[8] Purwanto, Evaluasi Hasil Belajar. Yogyakarta: Pustaka Belajar, 2011.

[9] Sugiyono, Metode Penelitian Pendidikan (Pendekatan Kuantitatif, Kualitatif dan R\&D). Bandung: Alfabeta, 2014.

[10] D. Octariani and I. H. Rambe, "Pengembangan Bahan Ajar Berbasis Project Based Learning Berbantuan Software Geogebra," MES J. Math. Educ. Sci., vol. 4, no. 1, pp. 16-21, Oct. 2018, DOI: 10.30743/MES.V4I1.864.

\section{CONCLUSION}

The draft project book of geotechnical engineering that is assisted by the Plaxis application which is developed from the results of the research from the development of geotechnical engineering project book based on the ICT has been done testing feasibility by 2 validators and 1 practical so that are obtained valid results to be developed and are very practical to be used as an effort to bring up the students's hard skills in the field of geotechnical engineering. Furthermore, the draft project book of that has been valid and very practical, it can be continued to find out its effectiveness by using the certain variables.

[11] M. D. Borg, W.R. \& Gall, Educational Research, An Intruduction, Fourth Edition. Newyork: Longman, 1989.

[12] Arifin Zainal, Penelitian Pendidikan metode dan Paradigma Baru. Medan: Remaja Rosda Karya, 2012.

[13] Sukardjo, Desain Pembelajaran Evaluasi Pembelajaran, Hand-out Perkuliahan. Yogyakarta: PPS: Universitas Negeri Yogyakarta, 2008.

[14] P. Urip, "Bahan Sosialisasi Standar Penilaian Buku Teks.” pp. 1-36, 2008, [Online]. Available: http://telaga.cs.ui.ac.id/ heru/bsnp/13oktober08/Ba han Sosialisasi Standar Penilaian Buku Teks Pelajaran TIK.ppt., 2008

[15] Eko.P.W, Evaluasi Program Pembelajaran. Yogyakarta: Pustaka Belajar, 2010.

[16] Suhairiani, N. H. Panjaitan, H. Batubara, S. Z. Yuzni, K. Wijaya, and E. K. Sinaga, "Testing the Feasibility of Practical Student Worksheets Based on the Soil Testing Module Learning," Feb. 2021, pp. 190-195, DOI: 10.2991/assehr.k.210203.115.

[17] \& S. A. M. Ating. S., Statistika Dalam Penelitian. Bandung: Pustaka Setia, 2006.

[18] Y. Ayriza and Y. Ayriza, "Penyusunan Dan Validasi Modul 'Social Life Skill' Bagi Pendidik Anak-Anak Prasekolah,” J. Penelit. dan Eval. Pendidik., vol. 12, no. 2, Sep. 2013, DOI: 10.21831/pep.v12i2.1428.

[19] S. Ida Kholida and H. Jufri Andi, "Seminar Nasional Hasil Penelitian Universitas Kanjuruhan Malang," 2017.

[20] Sungkono, Pengembangan dan Pemamfaatan Bahan Ajar Modul Dalam Proses Pembelejaran. Yogyakarta: Universitas Negeri Yogyakarta, 2003. 
[21] K. Nafiah, S. Suhadi, and M. S. Sari, "Validitas dan Kepraktisan Bahan Ajar Pengelolaan Spesies Asing Invasif Acacia Nilotica untuk Matakuliah Pengelolaan Sumberdaya Alam,” J. Pendidik. Teor. Penelitian, dan Pengemb., vol. 4, no. 5, pp. 654-659, May 2019, DOI: 10.17977/JPTPP.V4I5.12459.

[22] E. Aprilia Usman, "Preliminary Study In The Learning Book Development Using Inquiry Based Learning Model For Physics Learning Of Senior High School Class X," Accessed: Jul. 29, 2021. [Online]. Available: www.ijstr.org. 